\title{
5 Conservative treatment for PAD - Risk factor management
}

\author{
Ulrich Frank ${ }^{a}$ (Switzerland), Sigrid Nikola (Germany), and Jill Belch ${ }^{a}$ (UK) for the European \\ Society of Vascular Medicine \\ PAD Guideline Writing Group \\ aall co-first authors
}

\section{ESVM Board Authors}

Vinko Boc ${ }^{*}$ (Slovenia), Marianne Brodmann (Austria), Patrick H Carpentier (France), Ali Chraim* (Ukraine), Caitriona Canning (Ireland); Evangelos Dimakakos* (Greece), Anders Gottsäter (Sweden), Christian Heiss (Germany), Lucia Mazzolai (Switzerland), Juraj Madaric* (Slovakia), Dan Mircea Olinic* (Romania), Zsolt Pécsvárady* (Hungary), Pavel Poredoš (Slovenia), Isabelle Quéré (France), Karel Roztocil (ESVM President, Czech Republic), Agata Stanek (Poland), Dragan Vasic* (Serbia), Adriana Visonà (Italy), and Jean-Claude Wautrecht ${ }^{\star}$ (Belgium)

\section{ESVM Country Society Authors}

Miroslav Bulvas (Czech Republic), Mary-Paula Colgan (Ireland), Walter Dorigo (Italy), Graeme Houston (UK), Thomas Kahan (Sweden), Holger Lawall (Germany), Isak Lindstedt (Sweden), Guillaume Mahe (France), Romeo Martini (Italy), Giles Pernod (France), Stanislaw Przywara (Poland). Marc Righini (Switzerland), Oliver Schlager (Austria), and Piotr Terlecki (Poland)

${ }^{*}$ Indicates ESVM Board members who were also nominated by their Country Society as reviewers.

\subsection{Objectives of conservative PAD treatment}

The objectives of PAD treatment are to reduce the risk of future cardiovascular events (all Fontaine Stages) to improve walking performance, mobility and quality of life in Fontaine Stage II, and limb preservation, pain reduction and improved/

maintain quality-of-life in Fontaine Stages III and IV.

This chapter deals with cardiovascular risk and its management in patients with PAD.

\subsection{Cardiovascular risk management in PAD}

Basic conservative treatment consists in monitoring of and treatment for cardiovascular risk factors for atherothrombosis. This covers regular physical activity, weight reduction in overweight patients, nicotine abstention in smokers, antiplatelet medication, as well as treatment for arterial hypertension, dyslipidemia and diabetes mellitus [113-117].

\begin{tabular}{lcc}
\hline Recommendation & $\begin{array}{c}\text { Class of } \\
\text { recommendation }\end{array}$ & $\begin{array}{c}\text { Level of } \\
\text { evidence }\end{array}$ \\
\hline $\begin{array}{l}\text { Lifestyle changes are } \\
\text { recommended in the presence of } \\
\text { obesity and/or physical inactivity. }\end{array}$ & I & C \\
\hline
\end{tabular}

\subsubsection{Smoking}

Smoking is at present the most important risk factors for PAD. The corresponding amount of exposure (number of pack years) is associated with the severity of $\mathrm{PAD}$, a higher amputation rate, peripheral prosthetic bypass occlusion and mortality $[118,119]$. The rate of amputations is markedly increased among smokers. Smoking cessation has been evidenced to impact on progression of PAD [120, 121], yet its significance for walking performance in intermittent claudication is less definite.

The rate of abstinence can demonstrably be improved with nicotine replacement preparations, formal cessation programs and bupropion [122-124]. Regularly and medically addressing the problem, along with intensive supervision, is the key to withdrawal. Other options, including group therapy or nicotine replacement preparations, should also be considered and can be combined with one another.

\subsubsection{Depression}

The presence of concomitant reactive depression in patients with PAD has become increasingly important [125]. The development of depression appears to limit quality of life and walking performance to a significant extent. In turn, reduced walking performance may possibly have a causative effect on the development of reactive depressive conditions. Data from interventional studies of antidepressants or psychiatric treatment for patients with PAD have not yet become available. 


\begin{tabular}{|c|c|c|}
\hline Recommendation & $\begin{array}{l}\text { Class of } \\
\text { recommendation }\end{array}$ & $\begin{array}{l}\text { Level of } \\
\text { evidence }\end{array}$ \\
\hline $\begin{array}{l}\text { Smoking cessation (and } \\
\text { abstinence from other drugs } \\
\text { taken through smoke } \\
\text { inhalation, e.g. cannabis) is } \\
\text { recommended as being } \\
\text { urgently required in all PAD } \\
\text { stages. }\end{array}$ & 1 & A \\
\hline $\begin{array}{l}\text { It is recommended that } \\
\text { smokers are to be provided } \\
\text { with a cessation program } \\
\text { consisting of medical } \\
\text { supervision, group therapy and } \\
\text { nicotine replacement } \\
\text { considered. }\end{array}$ & 1 & A \\
\hline $\begin{array}{l}\text { In the absence of evidence on } \\
\text { the long-term effects, it is } \\
\text { recommended that eCigarettes } \\
\text { should be considered to aid } \\
\text { smoking cessation. In the light } \\
\text { of adverse effects on the } \\
\text { endothelium these should be a } \\
\text { short interim activity to reduce } \\
\text { habituation and making } \\
\text { smoking cessation possible. }\end{array}$ & Ila & C \\
\hline
\end{tabular}

\subsubsection{Dyslipidemia}

Elevated total cholesterol concentrations, increased levels of low-density lipoprotein (LDL) cholesterol, triglyceride and lipoprotein (a), and decreased high-density lipoprotein (HDL) levels [126] are independent risk factors for the development of PAD. An inverse correlation has been shown between the level of LDL cholesterol and the ABI in patients with newly diagnosed PAD [127].

In the Heart Protection Study (HPS), simvastatin significantly lowered the rates of vascular and cardiac events in patients with PAD, irrespective of the presence of CAD at the beginning of the study [128-130]. This also applied to patients with so called 'normal' cholesterol values - indeed benefit was seen down to total cholesterol levels of $3.5 \mathrm{mmol} / \mathrm{l}$. A cholesterol threshold value under which no benefit was detectable was not evidenced.

In prevention of vascular events and overall mortality, the most recent Cochrane analyses endorsed the benefits, cost efficiency and improved quality of life associated with statins, without accepting relevant undesirable effects even in low-risk patients [131].

The extent to which LDL values should be lowered in PAD patients remains unclear, no prospective interventional studies have so far been carried out in PAD alone patients. However, the results of the Improved Reduction of Outcomes: Vytorin Efficacy International Trial (IMPROVE-IT) supported the "LDL hypothesis" and suggested monitoring and the reduction of LDL values in patients at a high risk of cardiovascular disorders. Further the Fourier study [132] which enrolled 27,564 patients of which $13.2 \%(3,642)$ had symptomatic PAD, all of whom were on statin therapy evaluated benefit in the preplanned PAD subgroup. The full study which was placebo controlled, of evolocumab, showed a significant decrease in the combined CV endpoints of MI, Stroke, and death (HR $0.80,95 \%$ CI $0.73-0.88$ ) combined with a very good safety profile for very low levels of LDL. In the PAD subgroup, evolocumab significantly reduced the primary end point consistently in patients with PAD (hazard ratio [HR] 0.79; $95 \%$ confidence interval [CI], 0.66-0.94, and also reduced the risk of major adverse limb events in all patients (HR, 0.58; $95 \%$ CI, 0.38-0.88) [133]. This suggests that current targets are set to fall as these new drugs reach endpoint study conclusion.

The benefits of lipid lowering with statins and other lipid reducing agents in PAD is without doubt. Intriguingly, there is also some evidence in support of lipid lowering improving claudication. In the Scandinavian Simvastatin Survival Study (4S), simvastatin served to reduce the development of intermittent claudication in patients with coronary and stroke disease [128-134]. Further studies applying various doses of atorvastatin or simvastatin to treat patients with claudication yielded significantly improved pain-free or absolute walking distances compared to placebo after 3, 6, and 12 months. However, these studies examined small numbers of patient only [135-137].

Intensive statin therapy has been shown in retrospective studies to not only reduce $\mathrm{CV}$ mortality but also amputation $[138,139]$ and to enhance graft patency [140]. New data, recently available, shows that intensive statin therapy versus low intensity statin therapy better reduces adverse limb outcomes such as amputation [141].

Further consideration on additional therapy such as ezetimibe [142] and evolocumab [132], may need to be considered in this group which has such a high risk of further CV events.

The current European Society of Cardiology (ESC) guidelines recommend a lowering of LDL cholesterol depending on the overall cardiovascular risk to $<100 \mathrm{mg} / \mathrm{dl}(<2.58 \mathrm{mmol} / \mathrm{l})$ in high-risk patients and to $<70 \mathrm{mg} / \mathrm{dl}(<1.81 \mathrm{mmol} / \mathrm{l})$ in those at a very high risk including PAD patients (see the ESC Systematic Coronary Risk Evaluation [SCORE] system) [113]. To achieve these lower levels, monitoring of patient results, to ensure targets are reached, is crucial. Thus, it is not sufficient to merely start lipid lowering therapy, but the clinician must also ensure arrangements are in place for follow-up (e.g., in Primary Care) to ensure "treating to target".

Identical target values can be recommended for women and men. However the current US guidelines have disassociated themselves from LDL titration as a target value [143]. PAD patients are considered very high-risk patients and are to be given "intensive" statin treatment with the aim to effectively and tolerably lower vascular risk. Medical Care has to focus on concordance, as non-adherence has shown to be a considerable problem in everyday practice. 


\begin{tabular}{|c|c|c|}
\hline Recommendation & $\begin{array}{l}\text { Class of } \\
\text { recommendation }\end{array}$ & $\begin{array}{l}\text { Level of } \\
\text { evidence }\end{array}$ \\
\hline $\begin{array}{l}\text { It is recommended that in } \\
\text { patients with PAD, statins are } \\
\text { indicated for the prevention of } \\
\text { cardiovascular events. Statins } \\
\text { reduce morbidity and } \\
\text { mortality in PAD and are } \\
\text { recommended for secondary } \\
\text { prevention in all PAD patients } \\
\text { who tolerate such medication. }\end{array}$ & 1 & A \\
\hline $\begin{array}{l}\text { It is recommended that Lipid } \\
\text { levels are only important in } \\
\text { terms of achieving } \\
\text { recommended decreases, not } \\
\text { as a value to decide whether } \\
\text { or not to start a statin. }\end{array}$ & I & A \\
\hline $\begin{array}{l}\text { Based on the pleiotropic } \\
\text { (multifactorial) and plaque- } \\
\text { stabilizing effects of statins, } \\
\text { statins should be considered } \\
\text { for all PAD patients when } \\
\text { tolerated, independent of LDL } \\
\text { levels in all stages of disease. }\end{array}$ & Ila & C \\
\hline $\begin{array}{l}\text { It is recommended that in PAD } \\
\text { patients, } L D L \text { should be } \\
\text { lowered to } 1.8 \mathrm{mmol} / \mathrm{l}(70 \mathrm{mg} / \\
\text { dl) or reduced by } \geq 50 \% \text { if } \\
\text { pretreatment values are } 1.8- \\
3.5 \mathrm{mmol} / \mathrm{l}(70-135 \mathrm{mg} / \mathrm{dl})\end{array}$ & 1 & A \\
\hline $\begin{array}{l}\text { A high dose of a potent statin is } \\
\text { usually indicated, if tolerated, } \\
\text { (eg } 20-40 \mathrm{mg} \text { of rosuvastatin, } \\
40-80 \mathrm{mgs} \text { and above } \\
\text { atorvastatin or comparable } \\
\text { doses of potent other statins). }\end{array}$ & 1 & A \\
\hline $\begin{array}{l}\text { A combination of a statin } \\
\text { medication with ezetimibe can } \\
\text { be considered to get better } \\
\text { tolerance of the statin } \\
\text { medication (with reduced } \\
\text { doses) or to achieve the given } \\
\text { target values in LDL- } \\
\text { cholesterol. }\end{array}$ & Ila & B \\
\hline
\end{tabular}

The recent publication of the Fourier Study using the PCSK9 Inhibitor evolocumab, and its predefined sub-study of PAD [133], shows a significant decrease in both MACE and major adverse limb events (MALE). MACE in patients with PAD (hazard ratio [HR] 0.79; $95 \%$ confidence interval [CI], 0.66-0.94 and without PAD (HR 0.86; $95 \%$ CI, 0.80$0.93)$ and MALE (HR, 0.58; $95 \%$ CI, 0.38-0.88; $\mathrm{P}=0.0093)$.

$61 \%$ of PAD patients recruited had had an intervention, $40 \%$ had diabetes, and the evidence showed the lower the LDL the better in terms of CV outcome with no lower limit being recommended and no overt side effects from this lower LDL. However, at present cost precludes us treating all patients, although a cost benefit analyses shows acceptable cost-effective thresholds [144] and so we recommend the following therapeutic strategy:

No data are available to evidence reduced morbidity and mortality by treating elevated triglyceride levels and low HDL cholesterol values.

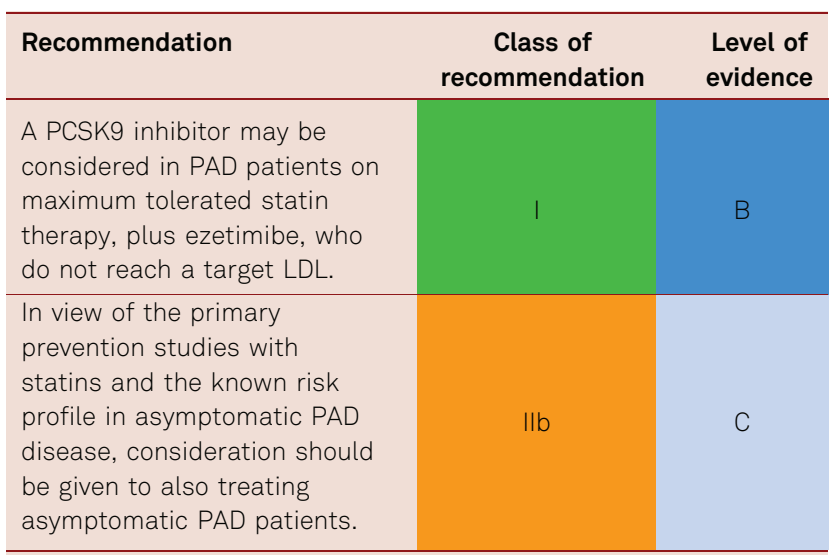

Nicotinic acid reduces femoral atherothrombosis and delays coronary atherothrombosis in patients with PAD [145], yet has no additional verified benefits compared to statins in terms of reduced clinical endpoints and so cannot be recommended [146]. Although, omega-3 fatty acids has shown no effect on platelet activation or inflammatory parameters in patients with $\mathrm{PAD}$, positive data are available for other risk populations [147-149]. However, there are no positive endpoint studies for patients with PAD [150, 151].

\begin{tabular}{llc}
\hline Recommendation & \multicolumn{1}{c}{$\begin{array}{c}\text { Class of } \\
\text { recommendation }\end{array}$} & $\begin{array}{c}\text { Level of } \\
\text { evidence }\end{array}$ \\
\hline $\begin{array}{l}\text { Nicotinic acid preparations } \\
\text { are not recommended in the } \\
\text { prevention of cardiovascular } \\
\text { events in patients with PAD }\end{array}$ & A \\
\hline $\begin{array}{l}\text { Omega-3 fatty acids are not } \\
\text { recommended in the } \\
\text { prevention of cardiovascular } \\
\text { events in patients with PAD. }\end{array}$ & III & $\mathrm{A}$ \\
\hline
\end{tabular}

\subsubsection{Diabetes mellitus}

Apart from smoking, diabetic metabolic disorders are the most important risk factors for PAD progression. Every $\mathrm{HbA}_{1 \mathrm{c}}$ increase in the magnitude of $1 \%$ is associated with a $28 \%$ increase in the relative risk for manifest PAD [152]. Diabetes elevates the risk of PAD by a factor of 3 to 4 and the risk of claudication by a factor of 2. A subgroup analysis of United Kingdom Prospective Diabetes Study (UKPDS) [40] in 3,884 patients showed a lower amputation rate with lower levels of $\mathrm{HbA}_{1 \mathrm{c}}$ and/or lower levels of chronic hyperglycemia [152]. Another study showed significantly reduced walking performance and lower-limb mobility in patients with diabetes with PAD compared with patients without diabetes with PAD [153].

Among type 2 patients with diabetes under intensified treatment (diabetes stabilization, CSE inhibitor i.e. statin and antiaggregant administration), the Steno-2 study observed a $25 \%$ relative risk reduction in amputation rates and a $10 \%$ decrease in vascular interventions over 7 years [154]. Both type 1 and type 2 patients with diabetes benefit from improved glucose stabilisation in terms of reduced PAD progression. Current guidelines issued by the 
American Diabetes Association (ADA), the European Association for the Study of Diabetes (EASD), and the European Society of Cardiology recommend the formulation of individualised treatment objectives for $\mathrm{HbA}_{1 \mathrm{c}}$ together with the affected patients, considering the factors of age, comorbidity, hypoglycemic risk and patient's preference. The aim is an $\mathrm{HbA}_{1 \mathrm{c}}$ range of $6.5 \%$ to $7.5 \%$ to prevent subsequent complications $[115,155,156]$. In elderly vascular patients, a range of $7 \%$ to $8 \%$, is seen as tolerable, while avoiding hypoglycemic events.

While 10-year follow-up data of the UKPDS has suggested a significant reduction in overall mortality, other studies have revealed no significant reduction in cardiovascular mortality by approximating the $\mathrm{HbA}_{1 \mathrm{c}}$ value to normal by way of intensified diabetes treatment. These include Action to Control Cardiovascular Risk in Diabetes (ACCORD [157]), Action in Diabetes and Vascular Disease: Preterax and Diamicron Modified Release Controlled Evaluation (ADVANCE [158]), Veterans Affairs Diabetes Trial (VADT [159]), Action in Diabetes and Vascular Disease: Preterax and Diamicron Modified Release Controlled Evaluation Post-trial Observational Study (ADVANCE-ON [160]).

The inconsistent database regarding the advantages of close-to-the-norm $\mathrm{HbA}_{1 \mathrm{c}}$ stabilization is the reason for querying the lowest possible $\mathrm{HbA}_{1 \mathrm{c}}$ target values and turning toward more individualised treatment strategies. Care for patients with vascular disorders and diabetic metabolic disorders requires interdisciplinary cooperation between vascular physicians and diabetologists.

Intentionally including pre-diabetes, the recent ESC/ EASD guidelines classified patients with diabetes in groups at high and at very high risk for cardiovascular events. Individual specification of treatment objectives, measured according to $\mathrm{HbA}_{1 \mathrm{c}}$ values and the avoidance of hypoglycemia, is the most important aspect of anti-hyperglycemic treatment. In individual cases, lifestyle interventions and treatment for comorbidities are to be applied.

\subsubsection{Antidiabetic therapy in PAD}

When it comes to diabetic therapy, the glucocentric view is increasingly taking a back seat. Rather, the treatment of cardiovascular comorbidities is of increasing importance. However, this is where there are considerable differences between the individual antidiabetic substances.

\section{Biguanides}

Metformin is the first-line oral antidiabetic drug in diabetics with PAOD, although the data is thin in this respect. A recently published study again demonstrates the positive effect on CV survival, but not on extremity retention and patency after peripheral revasculaization [161].

\section{Sulfonylureas and Glinides}

For both groups of substances no robust data on PAOD is available. Because of the relatively high risk of hypoglycemia and potential unfavorable effects in patients with coronary heart disease, these substances are hardly relevant [162].

\section{DPP4 inhibitors}

The cardiovascular endpoint studies SAVO-TIMI 53, EXAMINE, TECOS and CAROLINE show a non-inferiority of tested DPP4 inhibitors to the tested outcomes CV death, non-fatal myocardial infarction or stroke compared to placebo or glimepiride. In the SAVOR-Timi 53 study, however, significantly more hospitalization for saxagliptin was observed because of heart failure, so this substance should be used with caution in patients with known heart failure. Cardiovascular superiority or benefits in the presence of concomitant PAD are not proven [163-167].

\section{GLP1 agonists}

Both liraglutide, dulaglutide and semaglutide have been shown to have a positive effect on cardiovascular events such as fatal and non-fatal myocardial infarction and non-fatal stroke versus placebo in endpoint studies [168170]. In the LEADER study Liraglutide reduces the amputation rate.

For semaglutide, however, there is an increased rate of microvascular ocular complications in combination with insulin, which is why this GLP-1 agonist should not be used in patients with diabetic retinopathy [169].

\section{Thiazolidinediones (PPAR y agonists)}

For Pioglitazone the PROACTIVE and the IRIS study show positive endpoint in cardiovascular survival in type 2 diabetes and prediabetic patients [171-175] In the PROACTIVE trial, amputation was also considered the primary endpoint. Here, however, no significant advantage over the control group could be observed.

\section{SGLT-2 inhibitors}

For the substances empaglifozin, dapaglifozin and canaglifozin, the EMPAREG outcome study, the DECLARE-TIMI study and the CANVAS study provide data for positively influencing cardiovascular outcomes such as CV death, fatal and non-fatal myocardial infarction and stroke [176179]. The EMPAREG outcome study furthermore revealed a significantly reduction in amputations in PAOD whereas for canaglifozin a significantly increased amputation rate (mainly toe amputations) was observed. Although these are retrospective subgroup analyses, the use of canaglifozin in patients with diabetes and PAOD is currently not recommended.

\section{Insulin}

For basal insulin therapy, no endpoint studies are available for patients with PAOD. Insulin should be used in type 2 diabetics just in case of present cardiovascular complications, if possible, only after an optimized oral or GLP-1 based therapy.

In summery only empaglifozin and liraglutid have been shown to reduce amputations. Therefore, these substances should be considered in addition to metformin in patients with diabetes with previously known PAD [180, 181]. Screening for diabetes in patients with PAD should be 
carried out due to the close association between diabetes and PAD.

\begin{tabular}{|c|c|c|}
\hline Recommendation & $\begin{array}{l}\text { Class of } \\
\text { recommendation }\end{array}$ & $\begin{array}{l}\text { Level of } \\
\text { evidence }\end{array}$ \\
\hline $\begin{array}{l}\text { It is recommended that } \\
\text { patients with diabetes should } \\
\text { be screened for PAD }\end{array}$ & 1 & $B$ \\
\hline $\begin{array}{l}\text { It is recommended that all PAD } \\
\text { patients should be screened for } \\
\text { diabetes and effectively treated } \\
\text { in the case of a proven } \\
\text { diagnosis of diabetes. In type } 2 \\
\text { diabetics in addition to } \\
\text { metformin empaglifozin and/or } \\
\text { liraglutid should be considered. }\end{array}$ & 1 & B \\
\hline $\begin{array}{l}\text { Appropriate diabetic control is } \\
\text { recommended in patients with } \\
\text { PAD. }\end{array}$ & । & $B$ \\
\hline
\end{tabular}

\subsubsection{Hypertension}

Hypertension is associated with an increased prevalence of PAD [182]. The increase in risk is modest but the high prevalence of hypertension with increasing age makes the contribution of elevated blood pressure to incident PAD in the general population important. In men 40-79 years old the hazard ratio for incident PAD in the presence of hypertension was reported to be 2.42 [183], whilst a $20 \mathrm{~mm} \mathrm{Hg}$ increase in systolic blood pressure was associated with a $62 \%$ increased risk for PAD in a large population study [184].

Antihypertensive therapy unequivocally reduces cardiovascular events and mortality. Current evidence suggests a further benefit of reducing systolic blood pressure to lower values than previously recommended [185-187]. Thus, current guidelines recommend a target blood pressure, if tolerated, of $120-129 / 70-80 \mathrm{~mm} \mathrm{Hg}$ in patients below 65 years, and 130-139/70-80 mm Hg for older patients (with no upper age limit), also in people with concomitant cardiovascular disease (including PAD) and diabetes [188, 189]. A systolic blood pressure below $120 \mathrm{~mm} \mathrm{Hg}$ should not be targeted as it may increase the risk for acute coronary events and the risk of harm outweighs the benefits, in particular in patients with advanced CAD and in the old.

Angiotensin converting enzyme (ACE) inhibitors, angiotensin receptor blockers (ARB), calcium antagonists, and diuretics are all suited for blood pressure lowering treatment in patients with $\operatorname{PAD}[188,189]$. ACE inhibitors and ARB have been shown to reduce cardiovascular events in patients with arterial peripheral vascular diseases [190192]. ACE inhibitors were proposed to improve symptoms in patients with intermittent claudication [193] but this view has been revised [194] while the calcium antagonist verapamil was shown to prolong walking distance in patients with PAD [195]. Studies in hypertension show somewhat less reduction in cardiovascular events with beta blockers than with other antihypertensive drug classes. Of note, beta blockers are well tolerated in PAD patients and are not contraindicated [196-198]. Thus, beta blockers are useful in PAD patients with concomitant cardiovascular disorders, where they are indicated.

Most patients require two or more drug classes to achieve target blood pressure. Thus, a blocker of the renin-angiotensin aldosterone system in combination with a calcium antagonist or a diuretic is recommended, adding the third drug, if needed, to achieve target blood pressure. If blood pressure remains uncontrolled adding spironolactone may be considered, which provides a greater reduction in blood pressure than adding an alpha blocker or a beta blocker [Williams 2015]. However, beta blockers are recommended when there are specific clinical indications.

\begin{tabular}{|c|c|c|}
\hline Recommendation & $\begin{array}{l}\text { Class of } \\
\text { recommendation }\end{array}$ & $\begin{array}{l}\text { Level of } \\
\text { evidence }\end{array}$ \\
\hline $\begin{array}{l}\text { It is recommended that in } \\
\text { patients with PAD and arterial } \\
\text { hypertension, blood pressure } \\
\text { should be treated to reduce } \\
\text { cardiovascular events. }\end{array}$ & 1 & A \\
\hline $\begin{array}{l}\text { It is recommended that } \\
\text { systolic blood pressure should } \\
\text { be targeted to } 120-129 \mathrm{~mm} \\
\mathrm{Hg} \text {, if tolerated, in most } \\
\text { hypertensive patients aged } \\
\text { below } 65 \text { years, with or without } \\
\text { cardiovascular disease. }\end{array}$ & 1 & A \\
\hline $\begin{array}{l}\text { It is recommended that systolic } \\
\text { blood pressure should be } \\
\text { targeted to } 130-139 \mathrm{~mm} \mathrm{Hg} \text {, if } \\
\text { tolerated, in older ( } 65 \text { years } \\
\text { and above) hypertensive } \\
\text { patients, with or without } \\
\text { cardiovascular disease. }\end{array}$ & 1 & A \\
\hline $\begin{array}{l}\text { A diastolic blood pressure } \\
\text { below } 80 \mathrm{~mm} \mathrm{Hg} \text { should be } \\
\text { considered for all hypertensive } \\
\text { patients }\end{array}$ & Ila & B \\
\hline $\begin{array}{l}\text { Antihypertensive drug } \\
\text { treatment should consider } \\
\text { including an ACE inhibitors or } \\
\text { an angiotensin receptor blocker }\end{array}$ & Ila & B \\
\hline
\end{tabular}

\subsubsection{Platelet aggregation inhibitors in symptomatic PAD}

The clinical significance of decreased platelet aggregation in the secondary prevention of atherothrombotic vascular disorders is undisputed. However, large convincing studies showing a benefit of aspirin (ASA) in the reduction of vascular lesions in PAD have not yet been carried out. This applies to both PAD and the inhibition of progression in peripheral atherothrombosis. A primary meta-analysis carried out by the Antithrombotic Trialists' Collaboration failed to detect a significant decrease in cardiovascular events in PAD patients who were taking ASA and who presented no further vascular lesions in other organs. So, while there are conclusive study results regarding the secondary prevention of cardiac and cerebrovascular events in patients with PAD with antiplatelet agents other than 
Table 5.2.6. Recommendations on antithrombotic therapy in patients with Peripheral arterial disease.

\begin{tabular}{lcc}
\hline Recommendation & $\begin{array}{c}\text { Class of } \\
\text { recommendation }\end{array}$ & $\begin{array}{c}\text { Level of } \\
\text { evidence }\end{array}$ \\
\hline \multicolumn{1}{c}{ Lower extremity artery disease } & I & A \\
\hline Long term SAPT is recommended in symptomatic patients & 1 & $\mathrm{C}$ \\
\hline Long term SAPT is recommended in patients after revascularisation & $\mid$ & $\mathrm{A}$ \\
\hline Long term SAPT is recommended after infra-inguinal bypass surgery & $\mathrm{Ilb}$ & $\mathrm{B}$ \\
\hline In diabetic patients requiring SAPT clopidogrel may be preferred over aspirin $[16,179]$ & &
\end{tabular}

VKA may be considered after autologous infrainguinal bypass

DAPT at least 1 month after infrainguinal stent implantation

B

DAPT may be considered in below the knee prosthetic bypass graft

SAPT in asymptomatic patients

DAPT at least 1 month after drug coated balloon angioplasty

DAPT at least 3 months after drug eluting stent implantation

DAPT at least 3 months after covered stent implantation

Combination of aspirin $(100 \mathrm{mg} / \mathrm{d})$ and rivaroxaban $(2 \times 2.5 \mathrm{mg} / \mathrm{d})$ in patients with symptomatic disease

\section{Antithrombotic therapy for PAD Patients requiring oral anticoagulation (OAC)}

In patients with an indication for OAC, oral anticoagulation alone should be considered

After endovascular revascularisation aspirin or clopidogrel should be considered in addition to

OAC for at least 1 month

After endovascular revascularisation OAC alone should be considered if bleeding risks are high

OAC and SAPT may be considered if ischemic risk is high or there is another firm indication for long term SAPT

$\mathrm{AF}=$ atrial fibrillation; $\mathrm{CAS}=$ cartoid artery stenosis; $\mathrm{CHA}_{2} \mathrm{DS}_{2}$-VASC = Congestive heart failure, Hypertension, AGE $\geq 75$ (2 points), Diabetes Mellitus, Stroke or TIA (2 points), Vascular disease, Age 65-74 years, Sex category; DAPT = dual antiplatelet therapy; LEAD = lower extremity artery disease; OAC = oral anticoagulation; PADs = peripheral arterial diseases; SAPT = single antiplatelet therapy.

aspirin, the data base regarding the primary prevention of peripheral arterial events is insufficient and in part contradictory [199-201].

In a subsequent meta-analysis including many platelet aggregation inhibitors (ASA, clopidogrel, ticlopidine, dipyridamole, picotamide), a $23 \%$ reduction in the relative risk for ischemic events was seen in all patients with PAD [202] but most patients received ticlopidine in these studies.

The benefit of life-long antiplatelet treatment in patients with PAD to prevent CAD or cerebrovascular lesions does seem convincing $[9,16,203]$. Historically ticlopidine has been investigated in several studies in PAD patients and has shown to reduce the risk of MI, stroke and vascular death [204]. However, its benefits are limited by very frequent gastrointestinal side effects and potential side effects as neutropenia and thrombocytopenia. Therefore, clopidogrel, another thienopyridine derivative, has replaced ticlopidine. Clopidogrel was investigated in the CAPRIE study in which it proved efficacy in lowering the rates of MI, stroke and cardiovascular mortality. The overall benefit in the PAD subgroup compared with ASA was a $24 \%$ relative risk reduction [203]. In terms of numbers needed to treat (NNT) and compared to ASA, this corresponds to a total of 87 patients treated with clopidogrel over three years to avoid one additional cardiovascular event. In the current ESC PAD guidelines, clopidogrel was therefore recommended over aspirin in PAD patients [12] (Table 5.2.6).
In the EUCLID study [205], ticagrelor and clopigogrel were equivalent in effect, though there were more drug discontinuations for side effects with Ticagrelol. Disappointingly, there was no ASA arm. However, the significance of the novel $\mathrm{P}_{2} \mathrm{Y}_{12}$ adenosine receptor antagonists (prasugrel and ticagrelor) for PAD is still a matter of ongoing research. The daily dose of clopidogrel in secondary prophylaxis is $75 \mathrm{mg}$.

Based on the TRA 2P - TIMI 50 study, vorapaxar, a thrombin receptor (protease-activated receptor, PAR-1) antagonist, was granted approval in the US for the secondary preventive treatment of CAD and PAD (in combination with ASA or clopidogrel, to the exclusion of patients with cerebral arterial occlusive disease or a history of intracerebral bleeding due to the increased risk of cerebral bleeding in this patient group). Approval in Europe is limited to CAD. TRA 2P - TIMI 50 study yielded significant benefits in terms of vascular complications and mortality for patients with PAD and CAD treated with vorapaxar, a protease-activated receptor 1 (PAR 1) antagonist, yet no gain for those presenting with cerebral arterial occlusive disease [206].

The combination of ASA and clopidogrel in high-risk patients with multiple risk factors and atherothrombotic manifestations (including PAD) - as well as in patients presenting with risk factors for cardiovascular disorders resulted in an increased bleeding risk and no benefit [207].

Combination treatment across the board has no statistically significant risk reductions in terms of MI, stroke or 
Table 5.2.8. Preventive treatment for PAD and clinical benefits.

\begin{tabular}{|c|c|c|c|c|c|}
\hline Treatment & Agent & $\begin{array}{l}\text { Effect on morbidity } \\
\text { and mortality* }\end{array}$ & Effect on PAD* & $\begin{array}{l}\text { Effect on walking } \\
\text { performance* }\end{array}$ & Effect on $A B I$ \\
\hline Smoking abstinence & & $\begin{array}{l}\text { Reduction of } \\
\text { cardiovascular } \\
\text { mortality }\end{array}$ & & & \\
\hline \multirow[t]{3}{*}{ Cholesterol lowering } & Statin & $\begin{array}{l}12 \% \text { reduction in } \\
\text { overall mortality }\end{array}$ & $\begin{array}{l}38 \% \text { reduction in } \\
\text { the incidence of } \\
\text { intermittent } \\
\text { claudication }\end{array}$ & $\begin{array}{l}63 \% \text { increase in } \\
\text { pain-free walking } \\
\text { distances following } \\
1 \text { year of treatment }\end{array}$ & \\
\hline & Ezetimibe & $\begin{array}{l}5 \% \text { risk reduction in } \\
\text { combination with } \\
40 \text { mg simvastatin }\end{array}$ & & & \\
\hline & Evolocumab & $\begin{array}{l}12 \% \text { risk reduction } \\
\text { (95\% Cl, } 3 \text { to } 20 \text { ) in } \\
\text { the first year and } \\
19 \% \text { risk reduction } \\
\text { (95\% Cl, } 11 \text { to } 27 \text { ) } \\
\text { beyond the first year. }\end{array}$ & & & \\
\hline \multirow[t]{2}{*}{$\begin{array}{l}\text { Blood-pressure } \\
\text { lowering }\end{array}$} & Beta blockers & $\begin{array}{l}53 \% \text { reduction in } \\
\text { cardiovascular } \\
\text { events }\end{array}$ & & & \\
\hline & ACE inhibitors/ARBs & $\begin{array}{l}22 \% \text { reduction in } \\
\text { risk of } \\
\text { cardiovascular } \\
\text { events }\end{array}$ & & $\begin{array}{l}24 \% \text { improvement of } \\
\text { pain-free walking } \\
\text { distances; } 17.5 \% \\
\text { improvement of } \\
\text { maximum walking } \\
\text { distances }\end{array}$ & $\begin{array}{l}\mathrm{ABI} \text { increase from } \\
0.59 \text { to } 0.64\end{array}$ \\
\hline Diabetes treatment & & $\begin{array}{l}17 \% \text { reduction in } \\
\text { risk of } \\
\text { cardiovascular } \\
\text { events }\end{array}$ & $\begin{array}{l}25 \% \text { reduction in } \\
\text { major amputations }\end{array}$ & & \\
\hline Platelet inhibition & Clopidogrel & $\begin{array}{l}23.8 \% \text { reduction in } \\
\text { risk of } \\
\text { cardiovascular } \\
\text { events }\end{array}$ & & & \\
\hline$A S A+D O A C$ & $\begin{array}{l}\text { ASA } 100 \mathrm{mg} / \mathrm{d} \text { and } \\
\text { rivaroxaban } \\
2 \times 2.5 \mathrm{mg} / \mathrm{d}\end{array}$ & $\begin{array}{l}28 \% \text { net clinical } \\
\text { benefit HR 0.80) }\end{array}$ & $\begin{array}{l}46 \% \text { reduction of } \\
\text { major adverse limb } \\
\text { events including } \\
\text { major amputation } \\
\text { (HR } 0.54)\end{array}$ & & \\
\hline
\end{tabular}

Source: [216] (modified); *Relative risk reduction.

cardiovascular death. Therefore, combination treatment cannot be generally recommended for all patients with PAD. However, data from PEGASUS-TIMI 54 study [208, 209] prove that, in PAD patients with previous myocardial infarction, a selected high ischemic-risk subgroup, dual-antiplatelet therapy with aspirin and low-dose ticagrelor (60 $\mathrm{mg}$ b.i.d) is associated with a $5.2 \%$ AR reduction in MACE and a reduction of MALE, while major TIMI bleedings were in excess of only $0.12 \%$. Therefore, DAPT with ticagrelor $60 \mathrm{mg}$ b.i.d and aspirin may be considered in PAD patients with prior MI up to 3 years following the cardiac event. Evidence for prolonged treatment is currently lacking [12].

Evidence for dipyridamole in PAD is absent and is thus not indicated.

In summary, every symptomatic PAD patient should be given long-term treatment with platelet aggregation inhibitors, if there are no contraindications, as evidenced by the metaanalysis of the Antithrombotic Trialists' Collaboration and data from the Swedish Ticlopidine Multicentre Study (STIMS) and the Clopidogrel versus Aspirin in Patients at Risk of Ischemic Events (CAPRIE) study [42, 199, 207].

\begin{tabular}{llc}
\hline Recommendation & \multicolumn{1}{c}{$\begin{array}{c}\text { Class of } \\
\text { recommendation }\end{array}$} & $\begin{array}{c}\text { Level of } \\
\text { evidence }\end{array}$ \\
\hline $\begin{array}{l}\text { In patients with symptomatic } \\
\text { PAD, platelet aggregation } \\
\text { inhibitors are indicated for the } \\
\text { secondary prevention of } \\
\text { cardiovascular events. } \\
\text { Clopidogrel may be preferred } \\
\text { over aspirin. }\end{array}$ & A \\
\hline
\end{tabular}

\subsubsection{Platelet aggregation inhibitors in asymptomatic PAD}

In asymptomatic disease, there is no evidence for the use of aspirin. Patients with diabetes with asymptomatic PAD given $100 \mathrm{mg}$ daily of ASA, have shown neither reduced rates of cardiovascular events (lethal and nonlethal MI, stroke, cardiovascular mortality) nor reduced rates of major amputations compared to placebo-treated patients $[17,200,201]$. Amongst other reasons, the authors attributed this result to the wide application of statins in this 
high-risk group [167]. A large-scale, double-blind randomized population study covering a total of 28,980 Scottish residents found no clinically conspicuous cardiovascular disorders among 3,500 individuals with a decreased ABI score of $\leq 0.95$. After a median treatment and follow-up period of 8.2 years, administration of ASA $100 \mathrm{mg} /$ day orally had yielded no difference in the rate of cardiovascular events compared to placebo [210]. The benefit of antiplatelet agents in reducing peripheral arterial events has only been evidenced for patients given invasive endovascular treatment $[42,204]$.

\subsubsection{Anticoagulants}

From a peripheral arterial perspective, there is no indication for full dose INR lowering oral anticoagulation with vitamin $\mathrm{K}$ antagonists in patients with $\mathrm{PAD}$, provided that there is no acute embolic event. However, the effect of a low dose antithrombotic therapy with the new oral anticoagulants in combination with ASA has been investigated.

In the COMPASS Trial [211], evaluating patients with $\mathrm{CAD}$, and $\mathrm{CAD}$ and $\mathrm{PAD}$, rivaroxaban and aspirin alone and in combination were studied in patients with stable atherosclerotic vascular disease. Those assigned to rivaroxaban (2.5 mg twice daily) plus ASA $100 \mathrm{mg}$ daily, had a $24 \%$ better total survival and cardiovascular outcome (HR $0.76(0.66-0.86)$ ) but more major bleeding events than those assigned to aspirin alone (HR 1.70 (1.402.05)). Rivaroxaban (5 mg twice daily) alone did not result in better cardiovascular outcomes than aspirin alone and resulted in more major bleeding events. Clearly a decision weighing up risks of $\mathrm{CV}$ event vs bleeding is required. The net benefit was $22 \%$ overall risk reduction of the stable $\mathrm{CAD} / \mathrm{PAD}$ population.

Additional analysis of the PAD subgroup (stable PAD, CAD with asymptomatic PAD and stable carotid stenosis patients) in the Compass trial population [212, 213] revealed, besides the $28 \%$ general survival benefit, an additional significant $46 \%$ reduction in major adverse limb events including major amputation (HR $0.5495 \%$ CI 0.350.82) for ASA $100 \mathrm{mg} / \mathrm{d}$ combined with Rivaroxaban $2 \times 2.5 \mathrm{mg} / \mathrm{d}$ compared to ASA $100 \mathrm{mg} / \mathrm{d}$ and placebo. The net benefit was $28 \%$ risk reduction for the PAD subgroup of COMPASS compared to the $24 \%$ MACE reduction in the CAPRIE subgroup [203]. Unfortunately, the comparator of the COMPASS trial was ASA instead of Clopidogrel.

\begin{tabular}{llc}
\hline Recommendation & \multicolumn{1}{c}{$\begin{array}{c}\text { Class of } \\
\text { recommendation }\end{array}$} & $\begin{array}{c}\text { Level of } \\
\text { evidence }\end{array}$ \\
\hline $\begin{array}{l}\text { Based on the results of the } \\
\text { COMPASS trial, the combined }\end{array}$ & \\
therapy of ASA $100 \mathrm{mg} / \mathrm{d}$ and \\
rivaroxaban $2 \times 2.5 \mathrm{mg} / \mathrm{d}$ \\
should be considered in PAD \\
patients without a high risk of \\
bleeding, or other \\
contraindications.
\end{tabular}

Rivaroxaban was also shown to be effective in these patients when suffering from mild to moderate heart failure [214]. An additional clinical trial (Voyager PAD) [215] comparing ASA $100 \mathrm{mg} / \mathrm{d}$ with and without $2 \times 2.5 \mathrm{mg}$ rivarox$\mathrm{aban} / \mathrm{d}$ - including symptomatic PAD patients undergoing a surgical- or catheter-based intervention- is underway. Also, other new oral anticoagulants are being tested in a clinical phase 3 trial in combination with ASA in this patient population. Table 5.2.8 gives an overview of the benefits of consistent treatment for cardiovascular risk factors in patients with PAD.

\section{References (excerpt Chapter 5)}

9. Diehm C, Schuster A, Allenberg JR, Darius H, Haberl R, Lange $S$, et al. High prevalence of peripheral arterial disease and comorbidity in 6880 primary care patients: cross-sectional study. Atherosclerosis. 2004 Jan;172(1):95-105.

12. Aboyans V, Ricco J-B, Bartelink M-LEL, Björck M, Brodmann M, Cohnert T, et al. 2017 ESC Guidelines on the Diagnosis and Treatment of Peripheral Arterial Diseases, in collaboration with the European Society for Vascular Surgery (ESVS) Document covering atherosclerotic disease of extracranial carotid and vertebral, mesenteric, renal, upper and lower extremity arteriesEndorsed by: the European Stroke Organization (ESO)The Task Force for the Diagnosis and Treatment of Peripheral Arterial Diseases of the European Society of Cardiology (ESC) and of the European Society for Vascular Surgery (ESVS). European Heart Journal. 2018;39(9):763-816.

16. Hirsch AT, Criqui MH, Treat-Jacobson D, et al. Periphera arterial disease detection, awareness, and treatment in primary care. JAMA. 2001;286(11):1317-24.

17. Belch J, MacCuish A, Campbell I, Cobbe S, Taylor R, Prescott $\mathrm{R}$, et al. The prevention of progression of arterial disease and diabetes (POPADAD) trial: factorial randomised placebo controlled trial of aspirin and antioxidants in patients with diabetes and asymptomatic peripheral arterial disease. BMJ. 2008;337.

40. Engelhardt M, Boos J, Bruijnen $H$, Wohlgemuth W, Willy C, Tannheimer M, et al. Critical limb ischaemia: initial treatment and predictors of amputation-free survival. Eur $J$ Vasc Endovasc Surg. 2012 Jan;43(1):55-61.

42. Antithrombotic Trialists' Collaboration. Collaborative metaanalysis of randomised trials of antiplatelet therapy for prevention of death, myocardial infarction, and stroke in high risk patients. Bmj. 2002 Jan 12;324(7329):71-86.

113. Catapano AL, Graham I, De Backer G, Wiklund O, Chapman MJ, Drexel H, et al. 2016 ESC/EAS Guidelines for the Management of Dyslipidaemias. European Heart Journal. 37 (39):2999-3058.

114. Association AD. Standards of Medical Care in Diabetes2019. American Diabetes Association. 2019;42(Supplement 1):S4-S183.

115. Ryden L, Grant PJ, Anker SD, Berne C, Cosentino F, Danchin $\mathrm{N}$, et al. ESC Guidelines on diabetes, pre-diabetes, and cardiovascular diseases developed in collaboration with the EASD: the Task Force on diabetes, pre-diabetes, and cardiovascular diseases of the European Society of Cardiology (ESC) and developed in collaboration with the European Association for the Study of Diabetes (EASD). Eur Heart J. 2013 Oct;34(39):3035-87.

116. Mancia G, Fagard R, Narkiewicz K, Redon J, Zanchetti A, Bohm M, et al. 2013 ESH/ESC guidelines for the management of arterial hypertension: the Task Force for the Management of Arterial Hypertension of the European Society of Hypertension (ESH) and of the European Society of Cardiology (ESC). Eur Heart J. 2013 Jul;34(28):2159-219. 
117. Graham I, Atar D, Borch-Johnsen K, Boysen G, Burell G, Cifkova R, et al. Fourth Joint Task Force of the European Society of Cardiology and other Societies on Cardiovascular Disease Prevention in Clinical Practice (constituted by representatives of nine societies and by invited experts). European Journal of Cardiovascular Prevention 14(2_suppl):S1-S.

118. Hirsch AT, Treat-Jacobson D, Lando HA, Hatsukami DK. The Role of Tobacco Cessation, Antiplatelet and Lipid-Lowering Therapies in the Treatment of Peripheral Arterial Disease. Vascular Medicine. 1997;2(3):243-51.

119. Smith FB, Lowe GDO, Lee AJ, Rumley A, Leng GC, Fowkes FGR. Smoking, hemorheologic factors, and progression of peripheral arterial disease in patients with claudication. Journal of Vascular Surgery. 1998;28(1):129-35.

120. Willigendael EM, Teijink JAW, Bartelink M-L, Kuiken BW, Boiten J, Moll FL, et al. Influence of smoking on incidence and prevalence of peripheral arterial disease. Journal of Vascular Surgery. 2004;40(6):1158-65.

121. Aboyans V, Thomas D, Lacroix P. The cardiologist and smoking cessation. Current Opinion in Cardiology. 2010;25 (5):469-77.

122. Jorenby DE, Leischow SJ, Nides MA, Rennard SI, Johnston JA, Hughes AR, et al. A Controlled Trial of Sustained-Release Bupropion, a Nicotine Patch, or Both for Smoking Cessation. New England Journal of Medicine. 1999;340(9):685-91.

123. Steinberg MB, Greenhaus S, Schmelzer AC, Bover MT, Foulds J, Hoover DR, et al. Triple-combination pharmacotherapy for medically ill smokers: a randomized trial. Ann Intern Med. 2009 Apr 7;150(7):447-54.

124. Hennrikus D, Joseph AM, Lando HA, Duval S, Ukestad L, Kodl $\mathrm{M}$, et al. Effectiveness of a Smoking Cessation Program for Peripheral Artery Disease Patients. A Randomized Controlled Trial. 2010;56(25):2105-12.

125. Wattanakit K, Williams JE, Schreiner PJ, Hirsch AT, Folsom AR. Association of anger proneness, depression and low social support with peripheral arterial disease: the Atherosclerosis Risk in Communities Study. Vascular Medicine. 2005;10(3):199-206.

126. Tunstall-Pedoe H, Peters SAE, Woodward M, Struthers AD, Belch JJF. Twenty-Year Predictors of Peripheral Arterial Disease Compared With Coronary Heart Disease in the Scottish Heart Health Extended Cohort (SHHEC). Journal of the American Heart Association. 2017;6(9):e005967.

127. Daskalopoulou SS, Pathmarajah M, Kakkos SK, Daskalopoulos ME, Holloway PAH, Mikhailidis DP, et al. Association Between Ankle - Brachial Index and Risk Factor Profile in Patients Newly Diagnosed With Intermittent Claudication. Circulation Journal. 2008;72(3):441-8.

128. Collins R, Armitage J, Parish S, Sleigh P, Peto R, Heart Protection Study Collaborative Group. MRC/BHF Heart Protection Study of cholesterol-lowering with simvastatin in 5963 people with diabetes: a randomised placebocontrolled trial. Lancet (London, England). 2003;361 (9374):2005-16.

129. Heart Protection Study Collaborative Group. MRC/BHF Heart Protection Study of cholesterol lowering with simvastatin in 20536 high-risk individuals: a randomised placebocontrolled trial. The Lancet. 2002;360(9326):7-22.

130. Heart Protection Study Collaborative Group. Randomized trial of the effects of cholesterol-lowering with simvastatin on peripheral vascular and other major vascular outcomes in 20,536 people with peripheral arterial disease and other high-risk conditions. J Vasc Surg. 2007 Apr;45(4):645-54; discussion 53-4.

131. Taylor F, Huffman MD, Macedo AF, Moore THM, Burke M, Davey Smith G, et al. Statins for the primary prevention of cardiovascular disease. Cochrane Database of Systematic Reviews. 2013(1).

132. Sabatine MS, Giugliano RP, Keech AC, Honarpour N, Wiviott SD, Murphy SA, et al. Evolocumab and Clinical Outcomes in Patients with Cardiovascular Disease. New England Journal of Medicine. 2017;376(18):1713-22.
133. Bonaca MP, Nault P, Giugliano RP, Keech AC, Pineda AL, Kanevsky E, et al. Low-Density Lipoprotein Cholesterol Lowering With Evolocumab and Outcomes in Patients With Peripheral Artery Disease: Insights From the FOURIER Trial (Further Cardiovascular Outcomes Research With PCSK9 Inhibition in Subjects With Elevated Risk). Circulation. 2018 Jan 23;137(4):338-50.

134. Pedersen TR, Kjekshus J, Pyörälä K, Olsson AG, Cook TJ, Musliner TA, et al. Effect of simvastatin on ischemic signs and symptoms in the Scandinavian simvastatin survival study (4S). The American journal of cardiology. 1998;81(3):333-5.

135. Aronow WS, Nayak D, Woodworth S, Ahn C. Effect of simvastatin versus placebo on treadmill exercise time until the onset of intermittent claudication in older patients with peripheral arterial disease at six months and at one year after treatment. The American Journal of Cardiology. 2003:92(6):711-2.

136. Mohler ER, 3rd, Hiatt WR, Creager MA. Cholesterol reduction with atorvastatin improves walking distance in patients with peripheral arterial disease. Circulation. 2003 Sep 23;108 (12):1481-6.

137. Momsen AH, Jensen MB, Norager CB, Madsen MR, Vestersgaard-Andersen T, Lindholt JS. Drug Therapy for Improving Walking Distance in Intermittent Claudication: A Systematic Review and Meta-analysis of Robust Randomised Controlled Studies. European Journal of Vascular and Endovascular Surgery. 2009;38(4):463-74.

138. Sohn M-W, Meadows JL, Oh EH, Budiman-Mak E, Lee TA, Stone NJ, et al. Statin use and lower extremity amputation risk in nonelderly diabetic patients. Journal of Vascular Surgery. 2013;58(6):1578-85.e1.

139. Hsu C-Y, Chen Y-T, Su Y-W, Chang C-C, Huang P-H, Lin S-J. Statin Therapy Reduces Future Risk of Lower-Limb Amputation in Patients With Diabetes and Peripheral Artery Disease. The Journal of Clinical Endocrinology 102(7):2373-81.

140. Abbruzzese TA, Havens J, Belkin M, Donaldson MC, Whittemore AD, Liao JK, et al. Statin therapy is associated with improved patency of autogenous infrainguinal bypass grafts. Journal of Vascular Surgery. 2004;39(6):1178-85.

141. Arya S, Khakharia A, Binney ZO, DeMartino RR, Brewster LP, Goodney PP, et al. Association of Statin Dose With Amputation and Survival in Patients With Peripheral Artery Disease. Circulation. 2018 Apr 3;137(14):1435-46.

142. Cannon CP, Blazing MA, Giugliano RP, McCagg A, White JA, Theroux P, et al. Ezetimibe Added to Statin Therapy after Acute Coronary Syndromes. New England Journal of Medicine. 2015;372(25):2387-97.

143. Stone NJ, Robinson JG, Lichtenstein AH, Bairey Merz CN, Blum CB, Eckel RH, et al. 2013 ACC/AHA Guideline on the Treatment of Blood Cholesterol to Reduce Atherosclerotic Cardiovascular Risk in Adults. A Report of the American College of Cardiology/American Heart Association Task Force on Practice Guidelines. 2014;63(25 Part B):2889934.

144. Gregg C. Fonarow MBvH, PhD; Guillermo Villa, PhD; Jorge Arellano, MSc, MPhil; Peter Lindgren, PhD. Updated Costeffectiveness Analysis of Evolocumab in Patients With Very High-risk Atherosclerotic Cardiovascular Disease. 5th June 2019 ed. online: JAMA Cardiology; 2019.

145. Taylor AJ, Sullenberger LE, Lee HJ, Lee JK, Grace KA. Arterial Biology for the Investigation of the Treatment Effects of Reducing Cholesterol (ARBITER) 2: a double-blind, placebocontrolled study of extended-release niacin on atherosclerosis progression in secondary prevention patients treated with statins. Circulation. 2004 Dec 7;110(23):3512-7.

146. Hiatt WR, Hirsch AT, Creager MA, Rajagopalan S, Mohler ER, Ballantyne CM, et al. Effect of niacin ER/lovastatin on claudication symptoms in patients with peripheral artery disease. Vasc Med. 2010 Jun;15(3):171-9.

147. Marik PE, Varon J. Omega-3 dietary supplements and the risk of cardiovascular events: a systematic review. Clin Cardiol. 2009 Jul;32(7):365-72. 
148. Rizos EC, Ntzani EE, Bika E, Kostapanos MS, Elisaf MS. Association between omega-3 fatty acid supplementation and risk of major cardiovascular disease events: a systematic review and meta-analysis. Jama. 2012 Sep 12;308 (10):1024-33.

149. Mackay I, Ford I, Thies F, Fielding S, Bachoo P, Brittenden J. Effect of Omega-3 fatty acid supplementation on markers of platelet and endothelial function in patients with peripheral arterial disease. Atherosclerosis. 2012 Apr;221(2):514-20.

150. Grenon SM, Owens CD, Alley H, Chong K, Yen PK, Harris W, et al. n-3 Polyunsaturated fatty acids supplementation in peripheral artery disease: the OMEGA-PAD trial. Vasc Med. 2013 Oct;18(5):263-74.

151. Campbell A, Price J, Hiatt WR. Omega-3 fatty acids for intermittent claudication. Cochrane Database Syst Rev. 2013 Jul 4(7):CD003833.

152. Adler Al, Stevens RJ, Neil A, Stratton IM, Boulton AJM, Holman RR. UKPDS 59: Hyperglycemia and Other Potentially Modifiable Risk Factors for Peripheral Vascular Disease in Type 2 Diabetes. Diabetes Care. 2002;25(5):894-9.

153. Dolan NC, Liu K, Criqui MH, Greenland P, Guralnik JM, Chan C, et al. Peripheral Artery Disease, Diabetes, and Reduced Lower Extremity Functioning. Diabetes Care. 2002;25(1):113-20.

154. Gæde P, Vedel P, Larsen N, Jensen GVH, Parving H-H, Pedersen O. Multifactorial Intervention and Cardiovascular Disease in Patients with Type 2 Diabetes. New England Journal of Medicine. 2003;348(5):383-93.

155. Therapie des Typ 2 Diabetes. Nationale Versorgungsleitlinie 2013.

156. Inzucchi SE, Bergenstal RM, Buse JB, Diamant M, Ferrannini E, Nauck M, et al. Management of hyperglycemia in type 2 diabetes: a patient-centered approach: position statement of the American Diabetes Association (ADA) and the European Association for the Study of Diabetes (EASD). Diabetes Care. 2012 Jun;35(6):1364-79.

157. Gerstein HC, Miller ME, Byington RP, Goff DC, Jr., Bigger JT, Buse JB, et al. Effects of intensive glucose lowering in type 2 diabetes. N Engl J Med. 2008 Jun 12;358(24):2545-59.

158. Patel A, MacMahon S, Chalmers J, Neal B, Billot L, Woodward $\mathrm{M}$, et al. Intensive blood glucose control and vascular outcomes in patients with type 2 diabetes. N Engl $J$ Med. 2008 Jun 12;358(24):2560-72.

159. Veterans Affairs Diabetes Trial (VADT) Study Group, ADA Scientific Sessions. June 8, 2008.

160. Zoungas S, Chalmers J, Neal B, Billot L, Li Q, Hirakawa Y, et al. Follow-up of Blood-Pressure Lowering and Glucose Control in Type 2 Diabetes. New England Journal of Medicine. 2014;371(15):1392-406.

161. Khan SZ, Rivero M, Nader ND, Cherr GS, Harris LM, Dryjski $\mathrm{ML}$, et al. Metformin Is Associated with Improved Survival and Decreased Cardiac Events with No Impact on Patency and Limb Salvage after Revascularization for Peripheral Arterial Disease. Ann Vasc Surg. 2019 Feb;55:63-77.

162. Bannister CA, Holden SE, Jenkins-Jones S, Morgan CL, Halcox JP, Schernthaner G, et al. Can people with type 2 diabetes live longer than those without? A comparison of mortality in people initiated with metformin or sulphonylurea monotherapy and matched, non-diabetic controls. Diabetes Obes Metab. 2014 Nov;16(11):1165-73.

163. Scirica BM, Braunwald E, Raz I, Cavender MA, Morrow DA, Jarolim P, et al. Heart Failure, Saxagliptin, and Diabetes Mellitus: Observations from the SAVOR-TIMI 53 Randomized Trial. Circulation. 2015 Oct 13;132(15):e198.

164. White WB, Cannon CP, Heller SR, Nissen SE, Bergenstal RM, Bakris GL, et al. Alogliptin after acute coronary syndrome in patients with type 2 diabetes. N Engl J Med. 2013 Oct 3;369 (14):1327-35.

165. Zannad F, Cannon CP, Cushman WC, Bakris GL, Menon V, Perez AT, et al. Heart failure and mortality outcomes in patients with type 2 diabetes taking alogliptin versus placebo in EXAMINE: a multicentre, randomised, doubleblind trial. Lancet. 2015 May 23;385(9982):2067-76.
166. Green JB, Bethel MA, Armstrong PW, Buse JB, Engel SS, Garg J, et al. Effect of Sitagliptin on Cardiovascular Outcomes in Type 2 Diabetes. N Engl J Med. 2015 Jul 16;373(3):232-42.

167. Rosenstock J, et al., CAROLINA, ®. Cardiovascular safety and renal microvascular outcome with linagliptin in patients with T2D at high vascular risk. Oral presentation at the 79th Scientific Sessions of the American Diabetes Association (ADA), Monday, 10 June 2019, 16:30-18:30, San Francisco, CA, USA. 2019.

168. Marso SP, Daniels GH, Brown-Frandsen K, Kristensen P, Mann JFE, Nauck MA, et al. Liraglutide and Cardiovascular Outcomes in Type 2 Diabetes. New England Journal of Medicine. 2016;375(4):311-22.

169. Marso SP, Bain SC, Consoli A, Eliaschewitz FG, Jodar E, Leiter LA, et al. Semaglutide and Cardiovascular Outcomes in Patients with Type 2 Diabetes. N Engl J Med. 2016 Nov 10;375(19):1834-44.

170. Gerstein HC, Colhoun HM, Dagenais GR, Diaz R, Lakshmanan $\mathrm{M}$, Pais $\mathrm{P}$, et al. Dulaglutide and cardiovascular outcomes in type 2 diabetes (REWIND): a double-blind, randomised placebo-controlled trial. The Lancet. 2019;394(10193):12130.

171. Dormandy JA, Charbonnel B, Eckland DJA, Erdmann E, Massi-Benedetti M, Moules IK, et al. Secondary prevention of macrovascular events in patients with type 2 diabetes in the PROactive Study (PROspective pioglitAzone Clinical Trial In macroVascular Events): a randomised controlled trial. The Lancet. 2005;366(9493):1279-89.

172. Erdmann E, Dormandy JA, Charbonnel B, Massi-Benedetti M, Moules IK, Skene AM. The Effect of Pioglitazone on Recurrent Myocardial Infarction in 2,445 Patients With Type 2 Diabetes and Previous Myocardial Infarction: Results From the PROactive (PROactive 05) Study. Journal of the American College of Cardiology. 2007;49(17):1772-80.

173. Robert W, Marie-Germaine B, Betteridge DJ, Guntram S, Valdis $P$, Stuart K, et al. Effects of Pioglitazone in Patients With Type 2 Diabetes With or Without Previous Stroke: results From PROactive (PROspective pioglitAzone Clinical Trial In macroVascular Events 04). Stroke. 2007;38(3):865-73.

174. Lincoff AM, Wolski K, Nicholls SJ, Nissen SE. Pioglitazone and Risk of Cardiovascular Events in Patients With Type 2 Diabetes MellitusA Meta-analysis of Randomized Trials. JAMA. 2007;298(10):1180-8.

175. Kernan WN, Viscoli CM, Furie KL, Young LH, Inzucchi SE, Gorman M, et al. Pioglitazone after Ischemic Stroke or Transient Ischemic Attack. New England Journal of Medicine. 2016;374(14):1321-31.

176. Zinman B, Wanner C, Lachin JM, Fitchett D, Bluhmki E, Hantel S, et al. Empagliflozin, Cardiovascular Outcomes, and Mortality in Type 2 Diabetes. New England Journal of Medicine. 2015;373(22):2117-28.

177. Wanner C, Inzucchi SE, Lachin JM, Fitchett D, von Eynatten M, Mattheus M, et al. Empagliflozin and Progression of Kidney Disease in Type 2 Diabetes. New England Journal of Medicine. 2016;375(4):323-34.

178. Canagliflozin and Cardiovascular and Renal Events in Type 2 Diabetes. New England Journal of Medicine. 2017;377 (21):2097-9.

179. Wiviott SD, Raz I, Bonaca MP, Mosenzon O, Kato ET, Cahn A, et al. Dapagliflozin and Cardiovascular Outcomes in Type 2 Diabetes. New England Journal of Medicine. 2018;380 (4):347-57.

180. Holman RR, Coleman RL, Chan JCN, Chiasson J-L, Feng H, Ge $J$, et al. Effects of acarbose on cardiovascular and diabetes outcomes in patients with coronary heart disease and impaired glucose tolerance (ACE): a randomised, double-blind, placebo-controlled trial. The Lancet Diabetes 5(11):877-86.

181. Gerstein HC, Bosch J, Dagenais GR, Diaz R, Jung H, Maggioni $A P$, et al. Basal insulin and cardiovascular and other outcomes in dysglycemia. N Engl J Med. 2012 Jul 26;367 (4):319-28. 
182. Michael HC, Victor A. Epidemiology of Peripheral Artery Disease. Circulation Research. 2015;116(9):1509-26.

183. Joosten MM, Pai JK, Bertoia ML, Rimm EB, Spiegelman D, Mittleman MA, et al. Associations Between Conventional Cardiovascular Risk Factors and Risk of Peripheral Artery Disease in MenRisk of Peripheral Artery Disease in Men. JAMA. 2012;308(16):1660-7.

184. Emdin CA, Anderson SG, Callender T, Conrad N, SalimiKhorshidi G, Mohseni H, et al. Usual blood pressure, peripheral arterial disease, and vascular risk: cohort study of 4.2 million adults. BMJ : British Medical Journal. 2015;351:h4865.

185. Thomopoulos C, Parati G, Zanchetti A. Effects of blood pressure lowering on outcome incidence in hypertension: 7. Effects of more vs. less intensive blood pressure lowering and different achieved blood pressure levels - updated overview and meta-analyses of randomized trials. Journal of Hypertension. 2016;34(4):613-22.

186. Ettehad D, Emdin CA, Kiran A, Anderson SG, Callender T, Emberson J, et al. Blood pressure lowering for prevention of cardiovascular disease and death: a systematic review and meta-analysis. The Lancet. 2016;387(10022):957-67.

187. Reboussin DM, Allen NB, Griswold ME, Guallar E, Hong Y, Lackland DT, et al. Systematic Review for the 2017 ACC/ AHA/AAPA/ABC/ACPM/AGS/APhA/ASH/ASPC/NMA/PCNA Guideline for the Prevention, Detection, Evaluation, and Management of High Blood Pressure in Adults. A Report of the American College of Cardiology/American Heart Association Task Force on Clinical Practice Guidelines. 2017.

188. Whelton PK, Carey RM, Aronow WS, Casey DE, Collins KJ, Dennison Himmelfarb C, et al. 2017 ACC/AHA/AAPA/ABC/ ACPM/AGS/APhA/ASH/ASPC/NMA/PCNA Guideline for the Prevention, Detection, Evaluation, and Management of High Blood Pressure in Adults. A Report of the American College of Cardiology/American Heart Association Task Force on Clinical Practice Guidelines. 2017.

189. Williams B, Mancia G, Spiering W, Agabiti Rosei E, Azizi M, Burnier M, et al. 2018 ESC/ESH Guidelines for the management of arterial hypertension. European Heart Journal. 2018;39(33):3021-104.

190. Effects of an Angiotensin-Converting-Enzyme Inhibitor, Ramipril, on Cardiovascular Events in High-Risk Patients. New England Journal of Medicine. 2000;342(3):145-53.

191. Telmisartan, Ramipril, or Both in Patients at High Risk for Vascular Events. New England Journal of Medicine. 2008;358(15):1547-59.

192. Östergren J, for the Hsi, Sleight P, for the Hsi, Dagenais G, for the Hsi, et al. Impact of ramipril in patients with evidence of clinical or subclinical peripheral arterial disease. European Heart Journal. 2004;25(1):17-24.

193. Shahin Y, Barnes R, Barakat H, Chetter IC. Meta-analysis of angiotensin converting enzyme inhibitors effect on walking ability and ankle brachial pressure index in patients with intermittent claudication. Atherosclerosis. 2013 Dec;231 (2):283-90.

194. Vlachopoulos C, Terentes-Printzios D, Aboyans V, Brodmann M, De Carlo M, Tousoulis D. Angiotensin converting enzyme inhibitors and walking distance: Have we walked the whole distance? Atherosclerosis. 2016;252:199-200.

195. Jens Peder B, Per H, Flemming R, Hans Henrik K, Bent Skov J. Effect of Verapamil in Intermittent Claudication. Circulation. 1997;95(2):411-4.

196. Christine E-K, Gerhard W, Annika J, Savvas S, Ascan W, MirAbolfazl O, et al. Blockers in Patients With Intermittent Claudication and Arterial Hypertension. Hypertension. 2011;58(2):148-54.

197. Paravastu SCV, Mendonca DA, Da Silva A. Beta blockers for peripheral arterial disease. Cochrane Database of Systematic Reviews. 2013(9).

198. Soga Y, lida O, Takahara M, Hirano K, Suzuki K, Kawasaki D. Beta-blocker Treatment Does Not Worsen Critical Limb
Ischemia in Patients Receiving Endovascular Therapy. Journal of Atherosclerosis and Thrombosis. 2015;22 (5):481-9.

199. Sobel M, Verhaeghe R. Antithrombotic Therapy for Peripheral Artery Occlusive Disease: American College of Chest Physicians Evidence-Based Clinical Practice Guidelines (8th Edition). Chest. 2008;133(6, Supplement):815S43S.

200. Soejima H, Morimoto T, Saito Y, Ogawa H. Aspirin for the primary prevention of cardiovascular events in patients with peripheral artery disease or diabetes mellitus. Analyses from the JPAD, POPADAD and AAA trials. Thromb Haemost. 2010 Dec;104(6):1085-8.

201. Olinic DM, Tataru DA, Homorodean C, Spinu M, Olinic M. Antithrombotic treatment in peripheral artery disease. Vasa. 2018 Feb;47(2):99-108.

202. Clagett GP, Sobel M, Jackson MR, Lip GYH, Tangelder M, Verhaeghe R. Antithrombotic Therapy in Peripheral Arterial Occlusive Disease: The Seventh ACCP Conference on Antithrombotic and Thrombolytic Therapy. Chest. 2004;126 (3, Supplement):609S-26S.

203. A randomised, blinded, trial of clopidogrel versus aspirin in patients at risk of ischaemic events (CAPRIE). The Lancet. 1996;348(9038):1329-39.

204. Janzon L, Bergqvist D, Boberg J, Boberg M, Eriksson I, Lindgarde $F$, et al. Prevention of myocardial infarction and stroke in patients with intermittent claudication; effects of ticlopidine. Results from STIMS, the Swedish Ticlopidine Multicentre Study. J Intern Med. 1990 May;227(5):301-8.

205. Jones WS, Baumgartner I, Hiatt WR, Heizer G, Conte MS, White CJ, et al. Ticagrelor compared with clopidogrel in patients with prior lower extremity revascularization for peripheral artery disease. Circulation. 2017;135(3):241-50.

206. Morrow DA, Braunwald E, Bonaca MP, Ameriso SF, Dalby AJ, Fish MP, et al. Vorapaxar in the Secondary Prevention of Atherothrombotic Events. New England Journal of Medicine. 2012;366(15):1404-13.

207. Bhatt DL, Fox KAA, Hacke W, Berger PB, Black HR, Boden WE, et al. Clopidogrel and Aspirin versus Aspirin Alone for the Prevention of Atherothrombotic Events. New England Journal of Medicine. 2006;354(16):1706-17.

208. Bonaca MP, Bhatt DL, Cohen M, Steg PG, Storey RF, Jensen EC, et al. Long-Term Use of Ticagrelor in Patients with Prior Myocardial Infarction. New England Journal of Medicine. 2015;372(19):1791-800.

209. Bonaca MP, Bhatt D, Storey R, Steg P, Cohen M, Kuder J, et al. Efficacy and safety of ticagrelor as long-term secondary prevention in patients with prior myocardial infarction and peripheral artery disease. Journal of the American College of Cardiology. 2016;67(13 Supplement):2266.

210. Fowkes FG, Price JF, Stewart MC, Butcher I, Leng GC, Pell $\mathrm{AC}$, et al. Aspirin for prevention of cardiovascular events in a general population screened for a low ankle brachial index: a randomized controlled trial. Jama. 2010 Mar 3;303(9):841-8.

211. Eikelboom JW, Connolly SJ, Bosch J, Dagenais GR, Hart RG, Shestakovska O, et al. Rivaroxaban with or without Aspirin in Stable Cardiovascular Disease. New England Journal of Medicine. 2017;377(14):1319-30.

212. Anand SS, Bosch J, Eikelboom JW, Connolly SJ, Diaz R, Widimsky $P$, et al. Rivaroxaban with or without aspirin in patients with stable peripheral or carotid artery disease: an international, randomised, double-blind, placebo-controlled trial. The Lancet. 2018;391(10117):219-29.

213. Anand SS, Caron F, Eikelboom JW, Bosch J, Dyal L, Aboyans $\checkmark$, et al. Major Adverse Limb Events and Mortality in Patients With Peripheral Artery Disease: The COMPASS Trial. Journal of the American College of Cardiology. 2018;71(20):2306-15.

214. Kelley RB, Jeffrey LP, John WE, Jackie B, Aldo PM, Richard KC, et al. Rivaroxaban With or Without Aspirin in Patients With Heart Failure and Chronic Coronary or Peripheral Artery Disease. Circulation. 2019;140(7):529-37. 
215. Capell WH, Bonaca MP, Nehler MR, Chen E, Kittelson JM, Anand SS, et al. Rationale and design for the Vascular Outcomes study of ASA along with rivaroxaban in endovascular or surgical limb revascularization for peripheral artery disease (VOYAGER PAD). Am Heart J. 2018 May;199:83-91.

216. Bendermacher BL, Willigendael EM, Teijink JA, Prins MH. Medical management of peripheral arterial disease. J Thromb Haemost. 2005 Aug;3(8):1628-37.

\section{Correspondence address}

Prof. Jill JF Belch FRCP, MD (Hons), FRS(E), FMedSci, OBE

Professor of Vascular Medicine

Ninewells Hospital and Medical School

Dundee DD1 9SY

United Kingdom

j.j.f.belch@dundee.ac.uk 